\title{
Winter Habitat Use by American Marten, Martes americana, in Western Alberta Boreal Forests
}

\author{
GilberT ProulX
}

Alpha Wildlife Research \& Management Ltd., 229 Lilac Terrace, Sherwood Park, Alberta T8H 1W3 Canada

Proulx, Gilbert. 2006. Winter habitat use by American Marten, Martes americana, in western Alberta boreal forests. Canadian Field-Naturalist 120(1): 100-105.

Although the American Marten (Martes americana) is found in most forest regions of Alberta, little is known about its choice of winter habitats. This study investigated winter habitat use by American Marten in Weyerhaeuser's Grande Prairie Forest Management Area (FMA) using snowtracking along $128.2 \mathrm{~km}$ of seismic lines inventoried in winters 1999, 2002, and 2005 with snowmobiles. American Marten tracks $(n=44)$ occurred significantly less frequently than expected $(P<0.001)$ in immature/young pole stands, but more frequently than expected $(P<0.02)$ in mature/old growth mixedwood stands. American Martens apparently used young forests, and mature/old coniferous and deciduous stands, according to their availability. Forest development plans should be developed locally to retain late successional forests that meet the winter habitat requirements of American Marten.

Key Words: American Marten, Martes americana, forest management, winter habitat, Alberta.

Studies in coniferous forests of western North America suggest that American Martens (Martes americana) prefer late successional stands with vertical and horizontal structural complexity (Proulx et al. 2004). Koehler and Hornocker (1977) in Idaho, Campbell (1979) in Wyoming, and Koehler et al. (1990) in Washington reported that the highest level of American Marten activity was associated with mature Englemann Spruce - Subalpine Fir (Picea engelmannii - Abies lasiocarpa) forest type. In California, Spencer et al. (1983) concluded that optimal habitat for American Marten was extensive late successional forest. In British Columbia, most studies reported that American Martens used late successional coniferous forests. In the Sub-boreal Spruce Biogeoclimatic Zone, Lofroth (1993) found that American Martens preferentially included mature to old-growth forests in their home ranges. Proulx et al. (2005) described American Marten winter habitats in this biogeoclimatic zone as late-successional, circum-mesic stands with relatively high canopy closure and/or basal area. In the Boreal White and Black Spruce Biogeoclimatic Zone of northeastern British Columbia, Therrien (2002) found that American Martens preferred mature mixedwood forests. On the other hand, Poole et al. (2004) found that American Martens preferentially used mature coniferous forests but otherwise appeared to use all forested stands relative to their availability, including extensive deciduous and mixedwood stands $<40$ years of age.

Although American Marten is an important furbearer found in most forest regions of Alberta, little is known about its choice of winter habitats. I investigated winter habitat use by American Marten in Weyerhaeuser's Grande Prairie Forest Management Area (FMA) using snowtracking. On the basis of previous studies conducted in western North America, I hypoth- esized that American Marten tracks would be found mainly in late-successional forests.

\section{Study Area}

The Grande Prairie FMA $\left(55^{\circ} 11^{\prime} \mathrm{N}, 118^{\circ} 53^{\prime} \mathrm{W}\right)$ is a 1145 600-ha area located in northwestern Alberta, along the British Columbia border (Figure 1). Relief varies greatly, from undulating in the north and northeastern portions of the FMA, to mountainous areas, with elevations exceeding $1350 \mathrm{~m}$ in the south and southwest. Half of the FMA has a subhumid, continental climate with short, cool summers and long, cold winters (Alberta Government 1999*). The southern and southwestern half of the FMA has a subalpine climate, with below freezing temperatures occurring in all months and winter precipitation often exceeding $200 \mathrm{~cm}$ of snowfall (Alberta Government 1999*). The FMA is located within the Boreal vegetation zone, characterized by Engelmann Spruce, White Spruce (Picea glauca), Black Spruce (Picea mariana), Subalpine Fir, Balsam Fir (Abies balsamea), Lodgepole Pine (Pinus contorta), and Trembling Aspen (Populus tremuloides) in both pure and mixed stands (Looman and Best 1987; Alberta Government 1999*).

\section{Methods}

Snowtracking was conducted from 4 to 16 January 1999 ( 15 transects ranging in length from 0.2 to $8.7 \mathrm{~km}$; total: $41.1 \mathrm{~km}$ ), 12 to 27 February 2002 (14 transects ranging in length from 0.5 to $7.1 \mathrm{~km}$; total: $36 \mathrm{~km}$ ), and 20 January to 9 February 2005 (25 transects ranging in length from 0.8 to $4.3 \mathrm{~km}$; total: $51.2 \mathrm{~km}$ ). The number and length of inventory transects varied according to accessibility, safety, and environmental conditions. These corresponded to randomly selected 6-m wide seismic lines distributed across the FMA. The 


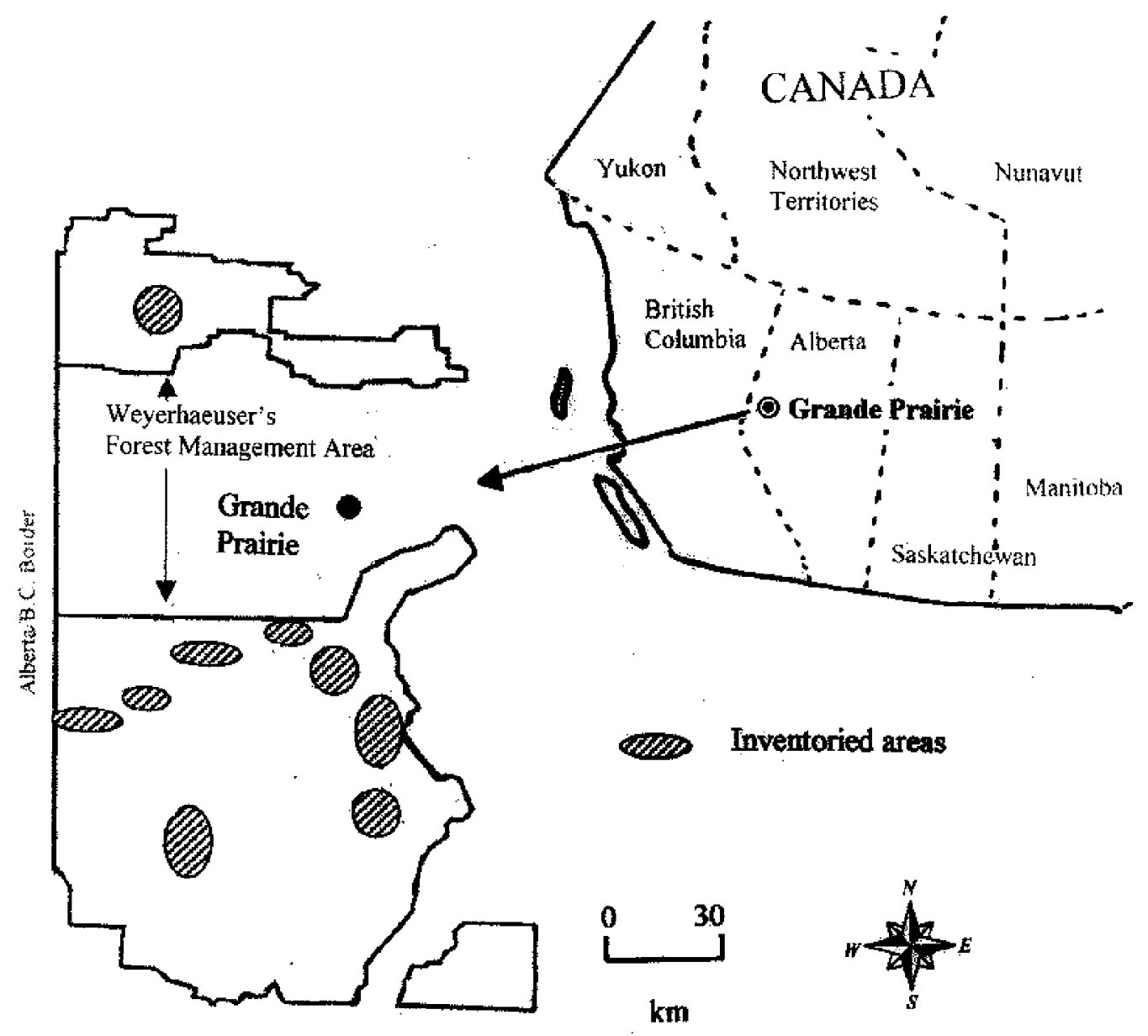

FIGURE 1. Location of Weyerhaeuser's Grande Prairie Forest Management Area (FMA) and inventoried regions in western Alberta.

same regions were investigated during the three inventories (Figure 1). A few seismic lines were used repeatedly over the years. In most cases, however, this was not possible because of access problems (overgrown vegetation, inappropriate snow conditions, or interfering gas exploration or logging activities), or transformation of seismic lines into roads or pipelines. Habitat type classification along inventory transects was based on Proulx and Kariz (2005) (Table 1).

Transects were traversed by snowmobiles $(<10 \mathrm{~km} / \mathrm{h})$. We recorded only tracks that were well-defined and judged to be fresh; i.e., less than $24 \mathrm{~h}$ old (subjective assessment based on the experience of the researcher). Due to the similarity between Fisher (Martes pennanti) and American Marten footprints (Halfpenny et al. 1995), when mustelid tracks were encountered, they were investigated on both sides of transects and within forest stands to find the best tracks available. The combination of footprint (pattern and size, presence/ absence of toe pad prints) and trail (gait, distance between jumps, and dragging of the feet) characteristics were used to identify tracks (Murie 1975; Rezendes 1992; Halfpenny et al. 1995). Fisher tracks are usually larger and farther apart, although the footprints of female Fishers and male American Martens may be of similar size. In winter, the undersurface of American Martens' feet is heavily covered with hair and toe pads do not show (Murie 1975; Rezendes 1992). The undersurface of Fishers' feet has sparse hair, and pads show well in clear prints (Halfpenny et al. 1995). Compared to American Martens, Fishers tend to walk more, leave straight trails, create troughs when walking in soft snow, drag their feet, and leave tail drag-marks in the snow (de Vos 1951; Raine 1983). Compared to American Martens, Fishers seldom tunnel under the snow (Halfpenny et al. 1995). Scats found on trails were also used 
TABLE 1. Habitat types used in the study of American Marten winter habitat use in 1999, 2002, and 2005 in Weyerhaeuser's Grande Prairie Forest Management Area, Alberta (after Proulx and Kariz 2005).

\begin{tabular}{|c|c|}
\hline Forest type & Characteristics \\
\hline $\begin{array}{l}\text { Deciduous } \\
\text { Coniferous } \\
\text { Mixedwood } \\
\end{array}$ & $\begin{array}{l}\text { Crown closure } \geq 10 \%, \text { deciduous species }>75 \% . \\
\text { Crown closure } \geq 10 \%, \text { coniferous species }>75 \% . \\
\text { Crown closure } \geq 10 \%, \text { neither type }>75 \%\end{array}$ \\
\hline Habitat type & Description \\
\hline Immature-Pole & $\begin{array}{l}0-40 \text { years old stands. Open areas and new stands. Pole stands are } \\
\text { thick stands of trees ( } 7.5 \text { to } 12.4 \mathrm{~cm} \text { diameter at breast height), } \\
\text { usually with little understory. }\end{array}$ \\
\hline Young & $\begin{array}{l}\text { 40-80 year-old forests. Achievement of dominance by some trees } \\
\text { and death of other trees leads to reduced competition that allows } \\
\text { understory plants to become established. The forest canopy has } \\
\text { begun differentiation into distinct layers. Vigorous growth and a } \\
\text { more open and multi-storied stand than in the pole stage. }\end{array}$ \\
\hline Mature-old & $\begin{array}{l}\geq 81 \text { years old late successional stands consisting mostly of mature } \\
\text { stands with even canopy of trees, with or without coarse woody } \\
\text { debris down and leaning logs. A few old stands with tall and large } \\
\text { canopy trees, canopy gaps, large snags, large downed woody } \\
\text { debris, and developed understories. A second cycle of shade } \\
\text { tolerant trees may have become established. }\end{array}$ \\
\hline
\end{tabular}

to identify animals. When encountering animals, footprints and trails were studied to ascertain criteria used to differentiate American Marten from Fisher.

Autocorrelation may occur during analysis of track survey data because of the uncertainty in whether one or more animals have made the tracks being counted (Proulx and O'Doherty 2006). It is sometimes difficult to confirm that a series of tracks along a transect belongs to the same animal (de Vos 1951), as home ranges overlap (Buskirk and Ruggiero 1994), and winter dispersal movements are known to occur (Clark and Campbell 1976). On the basis of track characteristics, Proulx et al. (2005) deduced that tracks of two different animals could be as close as $100 \mathrm{~m}$ from each other along the same transect. To minimize spatial autocorrelation, only tracks $>100 \mathrm{~m}$ apart within the same forest stand were recorded (Bowman and Robitaille 1997; Proulx et al. 2006).

In western North America, American Martens appear to be associated with late successional stands. Consequently, I hypothesized that American Marten tracks would not be distributed at random among habitat types, but that they would be more frequent in mature and old-growth stands. My hypothesis was declared before examining the track survey data. The proportion of inventory transects within each habitat type was used to determine the expected frequency of track intersects/habitat type (i.e., availability) if tracks were distributed randomly with respect to habitat types (Proulx et al. 2006). For each survey, I used a onetailed Fisher Probability test (Siegel 1956) to compare the proportion of American Marten tracks in the habitat growth types, i.e., mature/old vs. immature/young. Data from the three inventories were pooled to increase sample size. Chi-square statistics with Yates correction (Zar 1999) were used to compare observed to expected frequencies of track intersects among habitat type. If the chi-square analysis suggested an overall significant difference between the distribution of observed and expected frequencies, comparisons of observed to expected frequencies for each habitat class were conducted using the $\mathrm{G}$ test for correlated proportions (Sokal and Rohlf 1981). Probability values $\leq 0.05$ were considered statistically significant.

\section{Results}

Temperatures ranged from $-21^{\circ} \mathrm{C}$ to $0^{\circ} \mathrm{C}$ and snow depths exceeded $45 \mathrm{~cm}$ during each inventory. Inventories were conducted $\leq 24 \mathrm{~h}$ after snowfalls or flurries, thus assuring that tracks were fresh.

In $1999,41.1 \mathrm{~km}$ of transects were inventoried: $27.8 \mathrm{~km}(67.6 \%)$ in immature/young stands, and 13.3 $\mathrm{km}(32.4 \%)$ in mature/old stands. Eight tracks were recorded: $3(37.5 \%)$ in young stands, and $5(62.5 \%)$ in mature-old forests. The observed distribution of tracks was not significantly $(P=0.31)$ different from a random distribution of tracks among habitat types.

In $2002,36.0 \mathrm{~km}$ of transects were inventoried: 16.6 $\mathrm{km}(46 \%)$ in immature/young stands, and $19.4 \mathrm{~km}$ $(54 \%)$ in mature/old stands. Ten tracks were recorded: $1(10 \%)$ in a young stand, and $9(90 \%)$ in mature/old forests. The observed distribution of tracks was not significantly $(P=0.07)$ different from a random distribution of tracks among habitat types.

In $2005,51.1 \mathrm{~km}$ of transects were inventoried: $27.1 \mathrm{~km} \mathrm{(53 \% )} \mathrm{in} \mathrm{immature/young} \mathrm{stands,} \mathrm{and} 24 \mathrm{~km}$ $(47 \%)$ in mature/old forests. Twenty-six tracks were recorded: $6(23 \%)$ in young stands, and $20(77 \%)$ in 


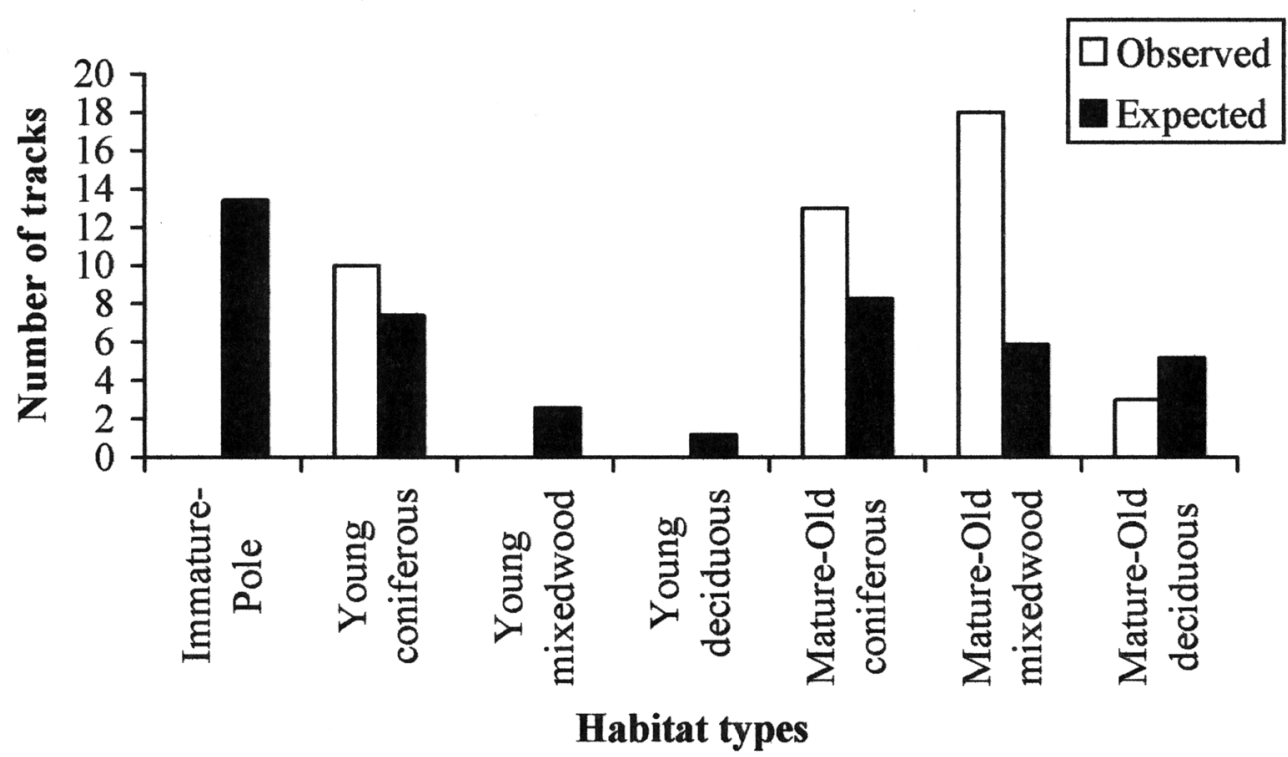

FIGURE 2. Observed and expected number of American Marten tracks per habitat type in Weyerhaeuser's Grande Prairie Forest Management Area.

mature-old forests. The observed distribution of tracks was significantly $(P=0.002)$ different from a random distribution of tracks among habitat types.

A total of $128.2 \mathrm{~km}$ of transects were inventoried from 1999 to $2005: 39.1 \mathrm{~km}(30.5 \%)$ in immature/pole stands, $32.5 \mathrm{~km}(16.9 \%$ in coniferous, $5.8 \%$ in mixed coniferous-deciduous, and $2.7 \%$ in deciduous) in young stands, and $44.2 \mathrm{~km} \mathrm{(18.8 \%} \mathrm{in} \mathrm{coniferous,} 13.5 \%$ in mixed coniferous-deciduous, and $11.9 \%$ in deciduous) in mature/old forests. Forty-four tracks were recorded: none in immature/pole stands, 10 tracks $(22.7 \%)$ in young coniferous forests, and 34 tracks $(77.3 \%)$ in mature/old stands (Figure 2). The observed distribution of American Marten tracks was significantly different from a random distribution of tracks among habitat types $\left(\chi^{2}=39\right.$, df: $\left.4, P<0.001\right)$ (Figure 2). Tracks were significantly less frequent than expected in immature/ pole stands $(\mathrm{G}=17.2$, df: $1, P<0.001)$, and more frequent than expected in mature/old mixedwood stands $(\mathrm{G}=6.42$, df: $1, P<0.02)$. The distribution of tracks suggested that American Martens used young forests, and mature/old coniferous and deciduous stands, according to their availability.

\section{Discussion}

In 1999 and 2002, because of small sample sizes, no significant difference was found in the distribution of American Marten tracks among habitat types. However, during both years, most tracks were in mature-old forests. Pooling data increased sample size and statistical power, and showed that American Marten tracks were definitely more frequent in late-successional stands. This finding is in agreement with previous studies conducted in western coniferous forests (Spencer et al. 1983; Wilbert 1992; Koehler et al. 1990; Therrien 2002; Proulx et al. 2006). American Martens prefer mature and old-growth forests over young and immature forests because this is where they maximize foraging efficiency and finding rest sites that can protect them from harsh environmental conditions (e.g., Powell et al. 2003).

Although young forests are believed to be suboptimal due to a reduction of necessary structure and diversity compared to mature and decadent forests (Thompson and Harestad 1994), in this study, nearly a quarter of American Marten tracks were located in young coniferous stands. As late/successional stands are decreasing in importance in Weyerhaeuser's FMA due to timber harvest, and oil and gas exploitation, American Martens may have to make greater use of young forests. However, previous studies showed that American Martens used young forests in winter where sufficient physical structure (Bowman and Robitaille 1997; Poole et al. 2004) and prey (Potvin et al. 2000) were present. More research on the characteristics of young forests used by American Martens is required to better understand their importance as winter habitat for this species in boreal ecosystems.

The fact that no tracks were recorded in immature and pole stands is in agreement with previous studies that have generally shown that American Martens make little or no use of early/successional stages 
(Steventon and Major 1982; Thompson 1994; Thompson and Harestad 1994; Chapin et al. 1998; Heinemeyer 2002; Poole et al. 2004). Previous studies have also shown that American Martens appear intolerant of habitat fragmentation, and they would not tolerate more than 30-35\% cutovers in their home range (Snyder and Bissonette 1987; Hargis and Bissonette 1997; Chapin et al. 1998; Potvin et al. 2000; Poole et al. 2004). In Weyerhaeuser's FMA, mature and old forests may be highly fragmented due to extensive clearcuts, and an important network of seismic lines and roads. Undoubtedly, these habitat modifications would have an impact on the distribution of American Martens, and cause shifts in home range boundaries (Poole et al. 2004). Forest development plans taking into consideration the winter habitat requirements of American Marten should therefore be developed locally according to the distribution of late/successional forests, cut blocks, and access networks (e.g., Proulx 2001*).

\section{Acknowledgments}

I thank Luigi Morgantini, Wendy Crosina, Dan Beilman, and Darren Lapp from Weyerhaeuser Company Ltd., and Pauline Feldstein from Alpha Wildlife, for helping with the project logistics. I also thank Vivian Banci, Valeria Vergara, and Jamie Farkvam for field assistance, and two anonymous referees for helpful comments.

\section{Documents Cited (marked $*$ in text)}

Alberta Government. 1999. Alberta natural regions. Alberta Environment Protection, Edmonton, Alberta.

Proulx, G. 2001. Characteristics and management of American marten habitat at stand and landscape levels. Alpha Wildlife Research \& Management Ltd. report prepared for British Columbia Ministry of Forests, Prince George Forest District, Prince George, British Columbia.

\section{Literature Cited}

Bowman, J. C., and J-F. Robitaille. 1997. Winter habitat use of American Martens Martes americana within secondgrowth forest in Ontario, Canada. Wildlife Biology 3: 97-105.

Buskirk, S. W., and L. F. Ruggiero. 1994. American Marten. Pages 7-37 in American marten, fisher, lynx, and wolverine in the Western United States. Edited by L. F. Ruggiero, K. B. Aubry, S. W. Buskirk, L. J. Lyon, and W. J. Zielinski. United States Department of Agriculture, Forest Service, General Technical Report RM-254, USA.

Campbell, T. M. 1979. Short-term effects of timber harvests on pine marten ecology. M.Sc. thesis, Colorado State University, Fort Collins, Colorado.

Chapin, T. G., D. J. Harrison, and D. D. Katnik. 1998. Influence of landscape pattern on habitat use by American marten in an industrial forest. Conservation Biology 12: 1327-1337.

Clark, T. W., and T. M. Campbell. 1976. Population organization and regulatory mechanisms of pine Martens in Grand Teton National Park, Wyoming. Pages 293-295 in Conference on scientific research in national parks. Volume 1. Edited by R. M. Linn, National Park Service Transactions Proceedings Series 5, Washington, D.C. de Vos, A. 1951. Tracking of fisher and marten. Sylva 7: 15-19.

Halfpenny, J. C., R. W. Thompson, S. C. Morse, T. Holden, and P. Rezendes. 1995. Snow tracking. Pages 91-163 in American marten, fisher, lynx and wolverine: survey methods for their detection. Edited by W. J. Zielinski and T. E. Kucera. United States Department of Agriculture, Forest Service Pacific Southwest Research Station General Technical Report PSW-GTR-157.

Hargis, C. D., and J. A. Bissonette. 1997. Effects of forest fragmentation on populations of American marten in the intermountain west. Pages 437-451 in Martes: taxonomy, ecology, techniques, and management. Edited by G. Proulx, H. N. Bryant, and P. M. Woodard. Provincial Museum of Alberta, Edmonton, Alberta.

Heinemeyer, K. S. 2002. Translating individual movements into population patterns: American marten in fragmented forested landscapes. Ph.D. thesis, University of California at Santa Cruz, California.

Koehler, G. M., J. A. Blakesley, and T. W. Koehler. 1990. Marten use of successional forest stages during winter in north-central Washington. Northwestern Naturalist 71:1- 4.

Koehler, G. M., and M. G. Hornocker. 1977. Fire effects on marten habitat in the Selway-Bitterroot Wilderness. Journal of Wildlife Management 41: 500-505.

Lofroth, E. C. 1993. Scale dependent analyses of habitat selection by marten in the Sub-boreal Spruce Biogeoclimatic Zone, British Columbia. M.Sc. thesis, Simon Fraser University, Burnaby, British Columbia.

Looman, J., and K. F. Best. 1987. Budd's flora of the Canadian Prairie Provinces. Agriculture Canada, Research Branch, Publication 1662.

Murie, O. J. 1975. A field guide to animal tracks. The Peterson's field guide series. Houghton Mifflin Co., Boston, Massachusetts, USA.

Poole, K. G., A. D. Porter, A. deVries, C. Maundrell, S. D. Grindal, and C. C. St. Clair. 2004. Suitability of a young deciduous-dominated forest for American marten and the effects of forest removal. Canadian Journal of Zoology 82: 423-435.

Potvin, F., L. Bélanger, and K. Lowell. 2000. Marten habitat selection in a clearcut boreal landscape. Conservation Biology 14: 844-857.

Powell, R.A., S. W. Buskirk, and W. J. Zielinski. 2003. Fisher and marten. Pages 635-649 in Wild mammals of North America. $2^{\text {nd }}$ edition. Edited by G. A. Feldhamer, B. C. Thompson, and J. A. Chapman.The Johns Hopkins University Press, Baltimore, USA.

Proulx, G., K. B. Aubry, J. Birks, S. W. Buskirk, C. Fortin, H. C. Frost, W. B. Krohn, L. Mayo, V. Monakhov, D. Payer, M. Saeki, M. Santos-Reis, R. Weir, and W. J. Zielinski. 2004. World distribution and status of the genus Martes in 2000. Pages 21-76 in Martens and fisher (Martes) in human-altered landscapes: an international perspective. Edited by D. J. Harrison, A. K. Fuller, and G. Proulx, Springer Science and Business Media, Inc., New York, New York.

Proulx, G., and R. Kariz. 2006. Winter habitat use by moose, Alces alces, in central interior British Columbia. Canadian Field-Naturalist 119: 186-191.

Proulx, G., R. Kariz, and J. Farkvam. 2006. Using forest inventory data to predict American marten distribution. Pages 77-88 in M. Santos-Reis, J. D. S. Birks, E. C. O'Doherty, and G. Proulx, editors. Martes in carnivore communities. Alpha Wildlife Publications, Sherwood Park, Alberta, Canada. 
Proulx, G., and E. C. O'Doherty. 2006. Snowtracking to determine Martes winter distribution and habitat use. Pages 211-224 in Martes in carnivore communities. Edited by M. Santos-Reis, J.D.S. Birks, E.C. O'Doherty, and G. Proulx, Alpha Wildlife Publications, Sherwood Park, Alberta, Canada.

Raine, R. M. 1983. Winter habitat use and responses to snow cover of fisher (Martes pennanti) and marten (Martes americana) in southern Manitoba. Canadian Journal of Zoology 61: 25-34.

Rezendes, P. 1992. Tracking and the art of seeing. Camden House Publishing, Inc., Charlotte, Vermont.

Siegel, S. 1956. Nonparametric statistics for the behavioral sciences. McGraw-Hill, New York, New York.

Snyder, J. E., and J. A. Bissonette. 1987. Marten use of clear-cutting and residual forest stands in western Newfoundland. Canadian Journal of Zoology 65: 169-74.

Sokal, R. R., and F. J. Rohlf. 1981. Biometry. $2^{\text {nd }}$ edition. W. H. Freeman and Co., San Francisco, California.

Spencer, W. D., R. H. Barrett, and W. J. Zielinski. 1983. Marten habitat preferences in the northern Sierra Nevada. Journal of Wildlife Management 47: 1181-1186.
Steventon, J. D., and J. T. Major. 1982. Marten use of habitat in a commercially clear-cut forest. Journal of Wildlife Management 46: 175-182.

Therrien, S. 2002. Habitat selection by marten (Martes americana) in managed mixedwood forests of the Boreal White and Black Spruce Biogeoclimatic Zone of Northeastern British Columbia. M.Sc. thesis, University of Victoria, Victoria, British Columbia.

Thompson, I. D. 1994. Marten populations in uncut and logged boreal forests in Ontario. Journal of Wildlife Management 58: 272-280.

Thompson, I. D., and A.S. Harestad. 1994. Effects of logging on American marten and models for habitat management. Pages 355-367 in Martens, sables, and fishers: biology and conservation. Edited by S. W. Buskirk, A. S. Harestad, M. G. Raphael, and R. A. Powell. Cornell University Press, Ithaca, New York.

Wilbert, C. 1992. Spatial scale and seasonality of habitat selection by martens in southeastern Wyoming. M.Sc. thesis, University of Wyoming.

Zar, J. H. 1999. Biostatistical analysis. $4^{\text {th }}$ edition, Prentice Hall, New Jersey.

Received 9 June 2005

Accepted 17 October 2005 